\title{
ON A NEW SCYPHOMEDUSA, PARAPHYLLINA RANSONI N.SP.
}

\author{
By F. S. Russell, F.R.S. \\ The Plymouth Laboratory
}

(Plates I and II, and Text-figs. I-3)

Maas (I903) described two specimens of a deep-water coronate scyphomedusa collected on the Siboga Expedition in the Malay Archipelago. He erected for these a new genus Paraphyllina and called the species $P$. intermedia. It differed from Periphylla in that the rhopalia were perradial and not interradial. In I903, Lo Bianco figured a specimen taken in the Mediterranean near Capri which was identified for him by Maas as $P$. dodecabostrycha (see also Maas, I904, p. 48, footnote); Mayer (I9I0) saw this specimen and re-described and figured it as Paraphyllina intermedia. A fourth specimen ascribed to this species by Ranson (I936) was found washed up on the shore at Villefranche.

All these specimens were the same in their essential characters, but differed in some details, especially in the form of the gonad and in the coloration.

In a deep-water haul with the $2 \mathrm{~m}$ ring trawl made by R.V. Sarsia on 28 April I955 with 500 fathoms of wire out off the mouth of the English Channel in $48^{\circ} 26^{\prime} \mathrm{N}$., $9^{\circ} 42^{\prime} \mathrm{W}$. some four dozen scyphomedusae were caught which belonged to the genus Paraphyllina. Most of the specimens, which ranged from I I to $35 \mathrm{~mm}$ in diameter, were in an excellent state of preservation.

These specimens agreed most closely with the medusa described by Ranson, and at first I was inclined to regard them as $P$. intermedia. Fortunately Dr P. L. Kramp suggested to me that the two original specimens described by Maas might still be in existence. On inquiry they were found to be in the Zoölogisch Museum at Amsterdam, and Professor H. Engel most generously sent these two type specimens to me to see.

Examination showed at once the adequacy of Maas' description, and that my specimens were not $P$. intermedia, and must therefore be regarded as a new species. As they are undoubtedly the same as the medusa described by Ranson (see footnote on p. IIO), I have great pleasure in naming this species Paraphyllina ransoni after Gilbert Ranson, whose researches have added much to our knowledge of medusae.

\section{Paraphyllina ransoni n.sp.}

Umbrella with hemispherical dome-shaped summit, with deep coronal groove situated somewhat nearer to the umbrella margin than to the summit, 
with fairly thick jelly, and with rectangular pedalial thickenings separated by deep furrows where the sixteen septal attachments of the upper and lower sides of the umbrella run. Rhopalial pedalia slightly narrower than the tentacular pedalia. Well-developed, continuous, coronal muscle band on subumbrella surface. Sixteen lappets with evenly rounded margins; the lappets on either side of the rhopalia are each a little more than two-thirds the width of those of the intertentacular pairs, and somewhat shorter on their rhopalial margins. Twelve solid marginal tentacles, eight adradial and four interradial; each about the length of the radius of the umbrella. Four perradial rhopalia, each with hood, statocyst and pigmented bulb, but no ocellus with lens. Eight adradial flattened elongated gonads, each forming an asymmetrical W whose interradially situated arms are coiled inwards and whose adradial arms bend outwards towards the perradii.

Stomach wall attached interradially to umbrella dome over four flattened triangular septal plates giving rise to four deep triangular pockets externally. Eight rows, or phacellae, each of about twenty or more simple gastric filaments, one along each side of the triangular septal plates. Four perradial horizontal entrances from stomach cavity into gastrovascular sinus, which is divided by the sixteen septa; each septum running from just above coronal muscle band to half the length of the marginal lappet, the rhopalial septa being slightly the longer. Manubrium slightly folded and reaching about to bases of marginal tentacles with four perradial thickenings and very slightly crenulated margin. Whole subumbrella and marginal tentacles uniformly coloured deep chocolate red, ${ }^{1}$ darkest in stomach but reaching right to umbrella margin; gonads colourless. Size up to $35 \mathrm{~mm}$ in diameter $(25 \mathrm{~mm}$ at coronal groove).

\section{FURTHER DetaILS}

Stomach. Each of the gastric filaments, which number about 160 or more in all, arises singly; very occasionally two may arise from one root. There are sometimes two or three terminal filaments at the apex of each triangular septal plate, and occasionally an isolated tuft of filaments on the stomach ceiling, presumably left behind during the downward movement of the areas of attachment as the umbrella grows.

Gonads. The W-shaped form of the gonads is very characteristic. Ranson's description of the gonads in his specimen agrees well with mine except that he said that each divides into three branches interradially. From Ranson's drawing the gonads have the appearance of being very fully developed.

In some of my specimens with most fully developed gonads the interradial areas of the $W$ may recoil upon themselves and overlie or even fuse with their neighbours, so that their true outlines are not very clear, or they may be abnormal in shape.

\footnotetext{
1 Specimens preserved in formalin and sea water.
} 


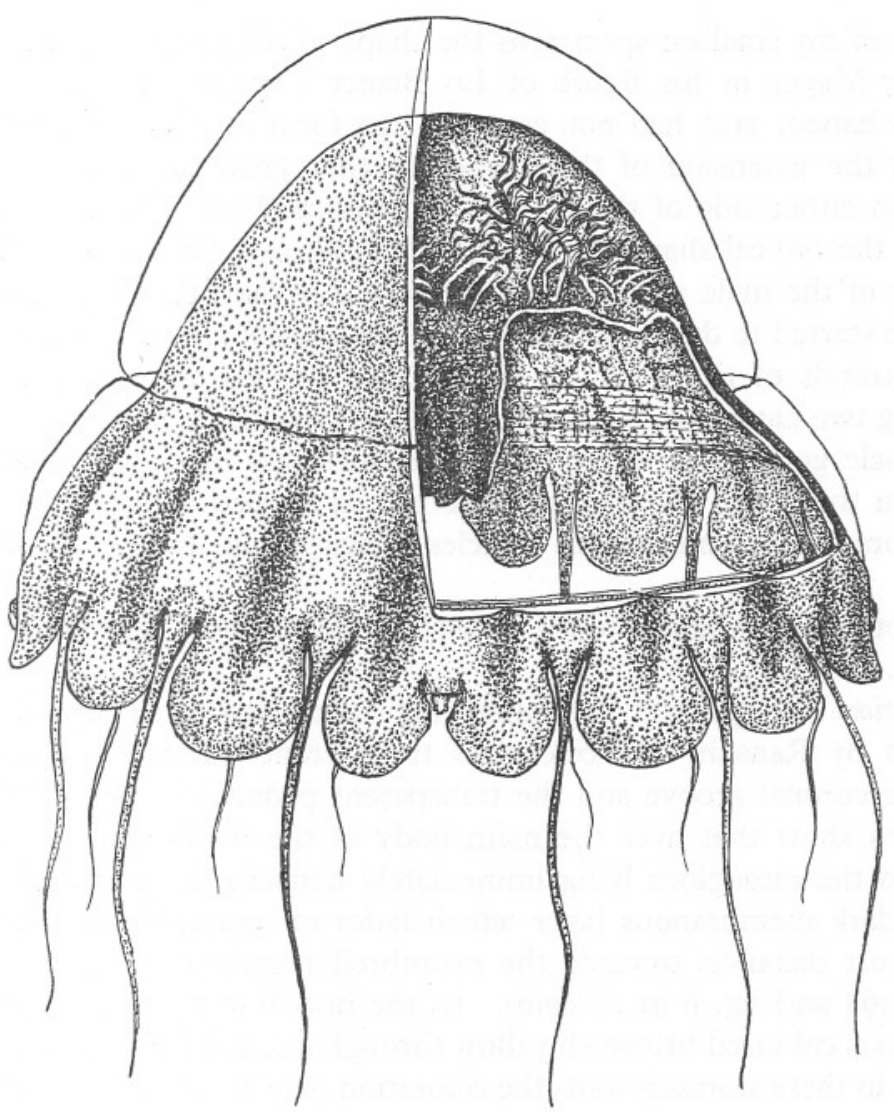

Text-fig. I. Paraphyllina ransoni. Adult medusa with a section of the umbrella and a portion of the manubrium cut away to show the subumbrella and internal anatomy.

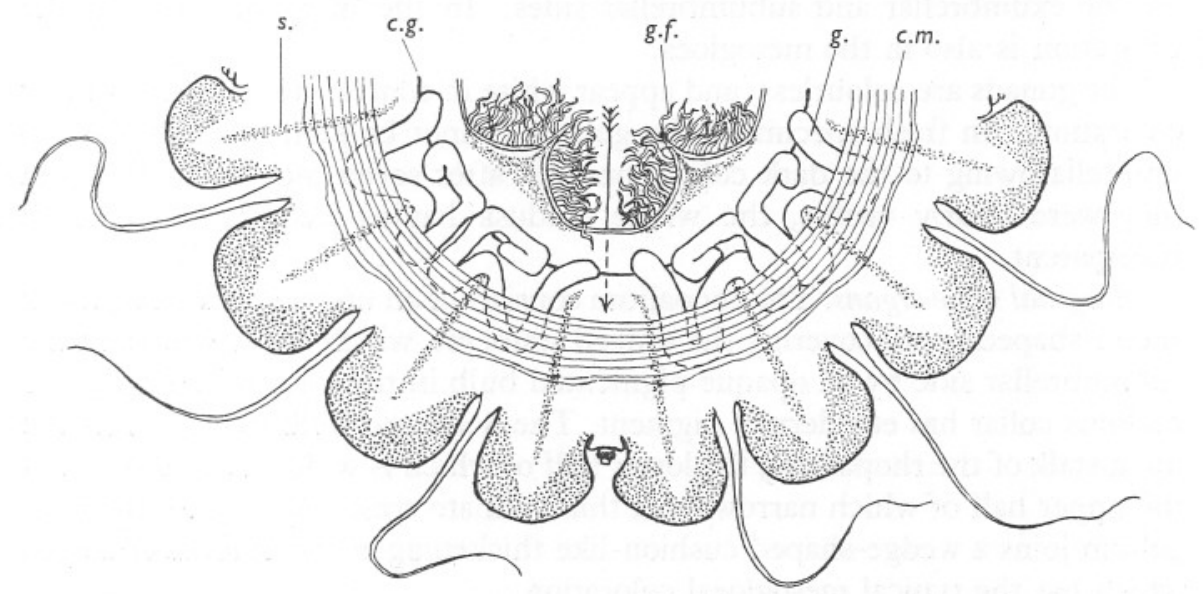

Text-fig. 2. P. ransoni. Semi-diagrammatic view of subumbrella with buccal walls of stomach cut away. The stippled areas indicate regions of fusion of upper and lower endoderm surfaces. The arrow shows a perradial entrance to the gastro-vascular sinus. c.g., coronal groove; c.m., coronal muscle; g., gonad; g.f., gastric filaments; s., septum. 
In one of my smallest specimens the shape of the gonads approached that shown by Mayer in his figure of Lo Bianco's specimen. They were still crescent-shaped, and had not assumed the form of a W which is brought about by the extension of the gonads as they grow towards the umbrella margin on either side of the septa. In practically all specimens, even the smallest, the typical shape of the gonad had already been assumed.

In one of the male specimens it appears that the fully developed gonads may have started to degenerate. Four of the gonads are reduced to crescentshaped strands of tissue (P1. II, fig. 2). Two gonads are complete, but the remaining two have been reduced to small pieces (Pl. II, fig. I).

In female gonads the ova are in different stages of development (Pl. II, fig. 4); in the males the spermatozoa are developed in elongated, oval or slightly branched seminiferous follicles arising from the gonad wall (Textfig. $3 d$ ).

The gonads are attached to the upper wall of the gastrovascular sinus along one edge.

Coloration. In general coloration my specimens were similar to that described by Ranson. The colourless transparent thickened dome of jelly above the coronal groove and the transparent pedalia are striking features.

Sections show that over the main body of the medusa the coloration is limited to the mesogloea lying immediately beneath the endoderm; here it forms a dark membranous layer which fades off gradually, but usually for only a short distance, towards the exumbrellar surface (cf. Fox \& Millott, 1954, p. 398 and fig. 6 in Pelagia). In the buccal walls of the stomach the mesogloea is coloured brownish yellow throughout, and is especially dark near the base; in these stomach walls the coloration may also be dense just beneath the outer ectodermal epithelium. The mesogloea of the marginal lappets is coloured throughout, and the thin dark zone is to be found here both on the exumbrellar and subumbrellar sides. In the marginal tentacles the coloration is also in the mesogloea.

The gonads are colourless, and appear white in contrast to the surrounding coloration. In fresh specimens the gonads cannot be seen through the exumbrella owing to the dark coloration; but after seven months in formalin they were clearly visible, the whole medusa having become much more transparent.

Marginal sense organs. The rhopalium consists of an upper short transparent spoon-shaped hood, covering the stalked statocyst, which is enveloped on the subumbrellar side by an opaque pigmented bulb in the form of a collar; this bulbous collar has ectodermal pigment. The hood and bulb fuse to form the main stalk of the rhopalium, the lower half of which is wide and rounded and the upper half of which narrows to a thin carinate crest. At its base the rhopalium joins a wedge-shaped cushion-like thickening of the umbrella margin, which has the typical mesogloeal coloration. 
Text-figs. $3 a-c$ show the general structure of the rhopalium, and a photograph of a radial section is given in Pl. II, fig. 3. It is to be noted that the pigment of the bulb is definitely on the outside in the ectoderm, and there is no ocellus with lens such as Maas described in $P$. intermedia.

Umbrella margin. In a few of my specimens the edges of the marginal lappets are undamaged, but in most they are somewhat frayed (see Pl. I, fig. I).
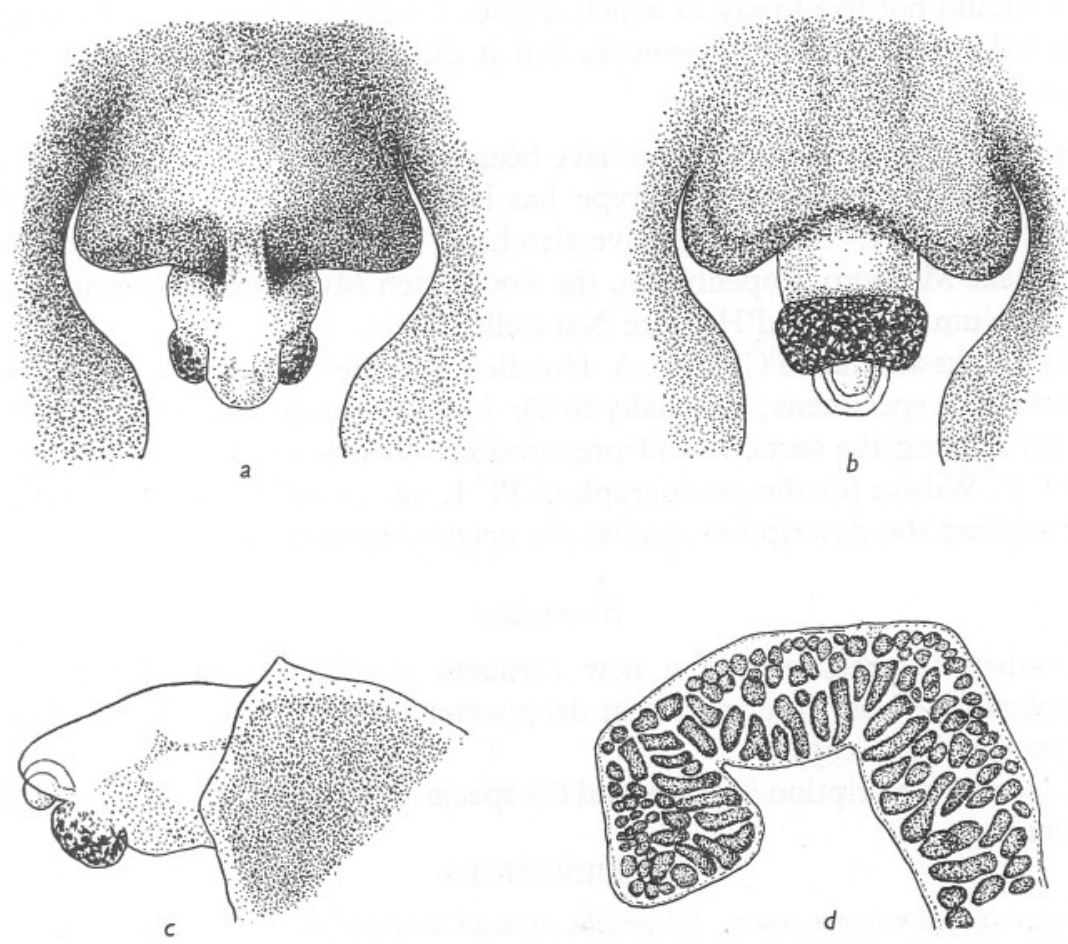

Text-fig. 3. P. ransoni. $a, b, c$ : exumbrellar, subumbrellar, and lateral views respectively of rhopalium ( $a, b$, reflected light; $c$, transmitted light); $d$, portion of male gonad.

Above the bases of the marginal tentacles and rhopalia there are six to eight, or more, radially directed dark stripes, typical of many coronate medusae. Sections show that these are thickenings of the mesogloea lying under the coronal muscle, which probably play a part by their elasticity in the contraction and expansion of the umbrella margin. They are clearly shown in Pl. I, fig. 2.

Size. The approximate total diameters of the medusae lying free in the formalin and sea water were as follows:

$\begin{array}{lcccccc}\text { Diameter }(\mathrm{mm}) & \mathrm{II}-\mathrm{I} 4 & \mathrm{I} 5-\mathrm{I} 9 & 20-24 & 25-29 & 30 & 35 \\ \text { No. of specimens } & 3 & \text { I3 } & \text { I4 } & 8 & 2 & 2\end{array}$


The differences between $P$. intermedia and $P$. ransoni may be summarized as follows:

\begin{tabular}{|c|c|c|}
\hline & P. intermedia & P. ransoni \\
\hline Colour & Limited to part of stomach & Over whole medusa \\
\hline Gonads & $\begin{array}{l}\text { Bean-shaped: above } \\
\text { muscle ring }\end{array}$ & $\begin{array}{l}\text { W-shaped: extending } \\
\text { under muscle ring }\end{array}$ \\
\hline ium & With ocellus with lens & Without ocellus with lens \\
\hline
\end{tabular}

It is now known ${ }^{1}$ that the medusa described by Ranson is $P$. ransoni, but I should not like to say to which species Lo Bianco's specimen belonged; in its coloration it fits $P$. intermedia but it differs from $P$. intermedia in the shape of its gonad.

Specimens from this collection have been deposited in the British Museum (Natural History) and the holotype has been given the registered number B.M. I955.II.2.I. Specimens have also been deposited in the Universitetets Zoologiske Museum, Copenhagen, the Zoölogisch Museum, Amsterdam, and the Muséum National d'Histoire Naturelle, Paris.

My thanks are due to Capt. C. A. Hoodless and the crew of R.V. Sarsia who collected the specimens; especially to Dr J. S. Alexandrowicz for much help and for making the sections and preparations illustrated in Pls. I and II; to Dr D. P. Wilson for the photograph in Pl. I, fig. I; and to Dr P. L. Kramp for checking the description against the original specimens.

\section{SUMMARY}

A number of specimens of a new coronate scyphomedusa of the genus Paraphyllina Maas were caught in deep water off the mouth of the English Channel in April 1955.

A detailed description is given, and the species has been named Paraphyllina ransoni $\mathrm{n} . \mathrm{sp}$.

\section{REFERENCES}

Lo Bianco, Salvatore, I903. Le pesche abissali eseguite da F. A. Krupp col Yacht Puritan nelle adiacenze di Capri ed in altre località del Mediterraneo. Mitt. zool. Sta. Neapel, Bd. I6, p. 219, Pl. 7, fig. 3.

Fox, D. L. \& Millott, N. I954. The pigmentation of the jellyfish Pelagia noctiluca (Forskål) var. panopyra Péron \& Lesueur. Proc. roy. Soc. B, Vol. I42, pp. 392-408, Figs. I-II.

MAAS, Otто, 1903. Die Scyphomedusen der Siboga-Expedition. Siboga Exped. Monogr. XI, pp. 6-IO, Pl. II, figs. IO-I4, Pl. XI, fig. IO6.

MaAs, OtTo, r904. Méduses provenant des campagnes des yachts Hirondelle et Princesse-Alice (1886-1903). Résult. Camp. sci. Monaco, Fasc. 28, p. 48.

MaYer, A. G., I9IO. Medusae of the World, Vol. III, p. 550, fig. 347.

RANSON, GILBERT, 1936. Observations morphologiques, systématiques et biogéographiques sur une Scyphoméduse rare, Paraphyllina intermedia O. Maas I903, trouvée sur la plage de Biarritz. Bull. Mus. Hist. Nat. Paris, 2nd Sér., T. 8, No. 3, pp. 269-76.

${ }^{1}$ Dr Ranson has confirmed this identity after seeing two of my specimens. 


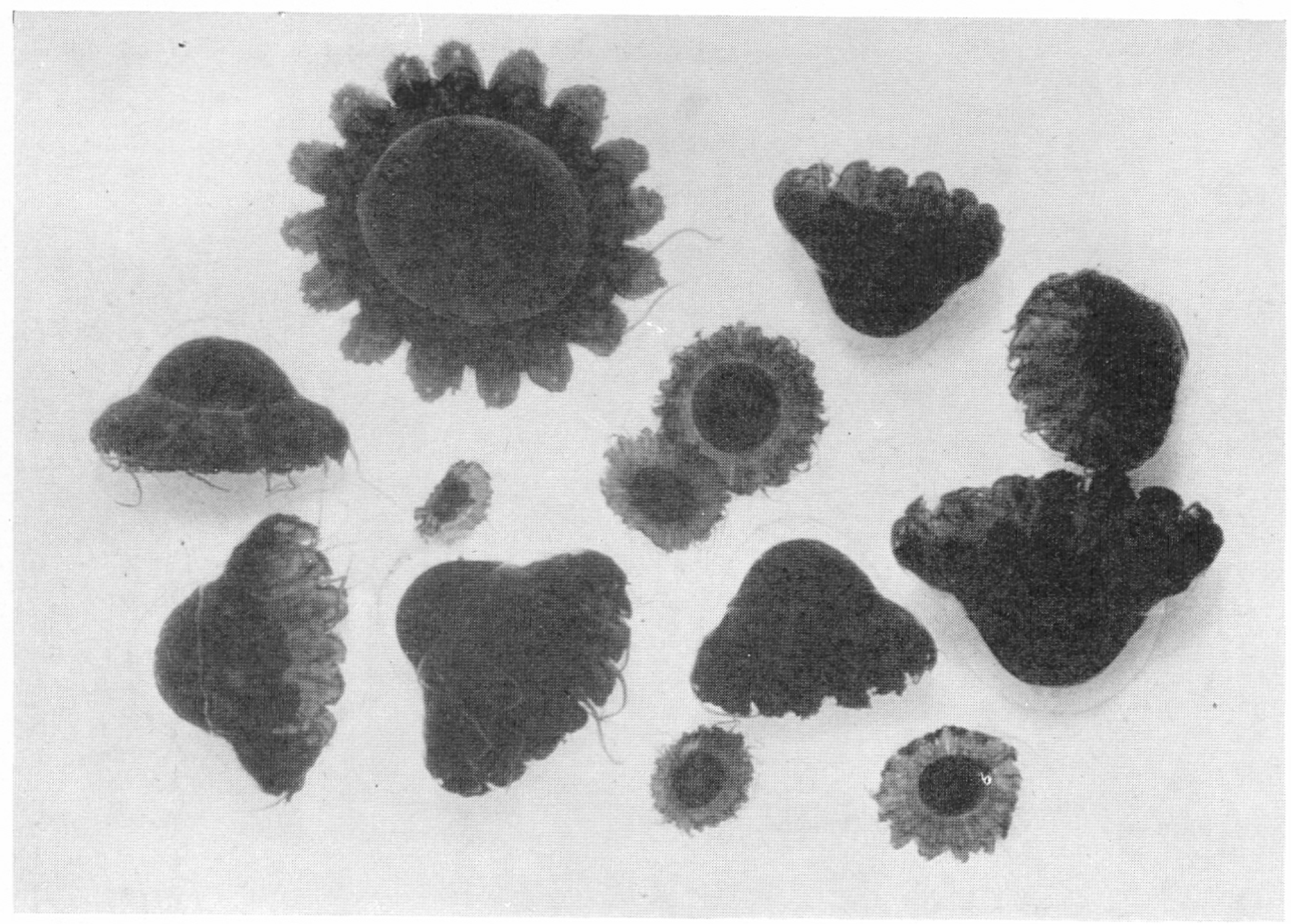

Fig. I

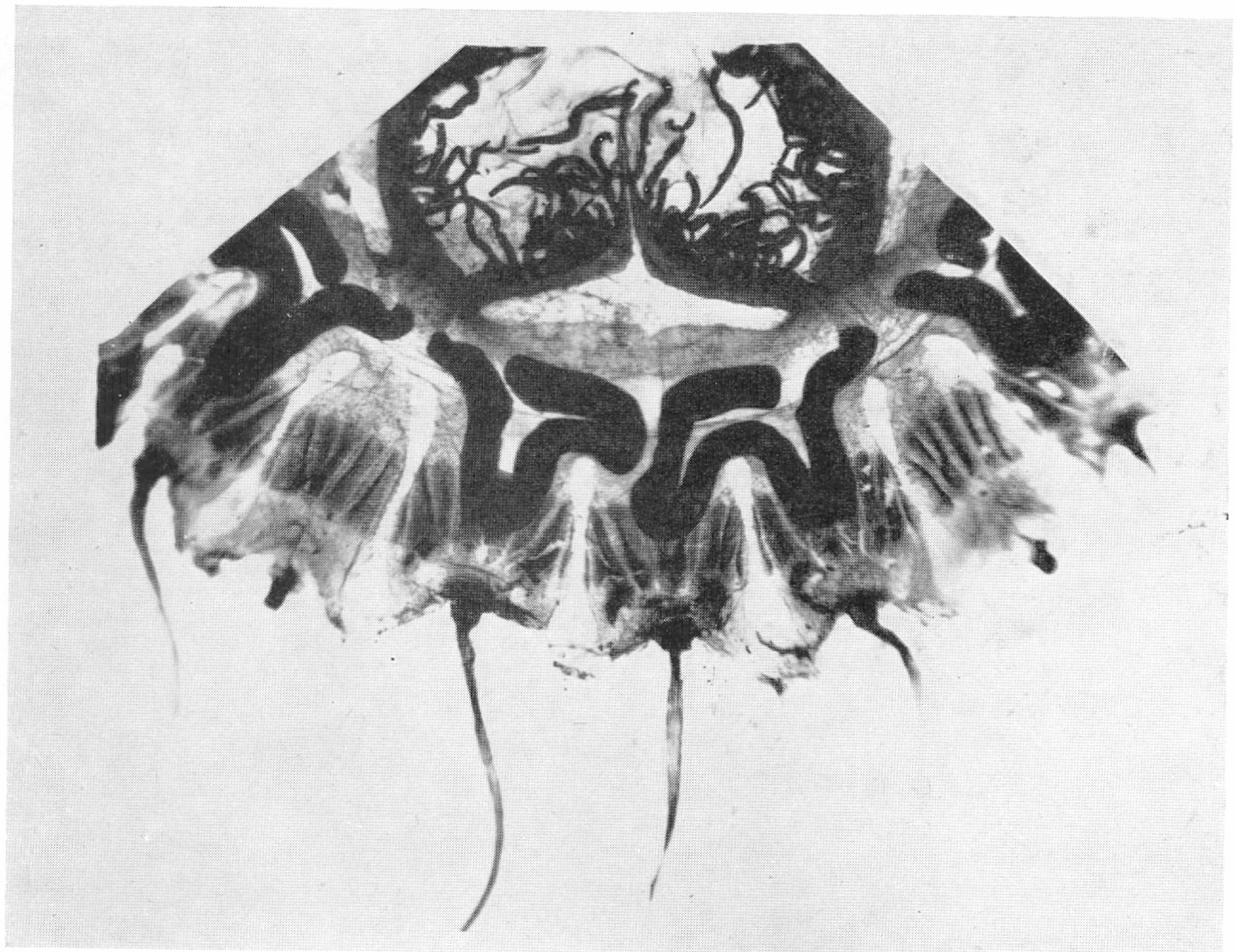

Fig. 2 

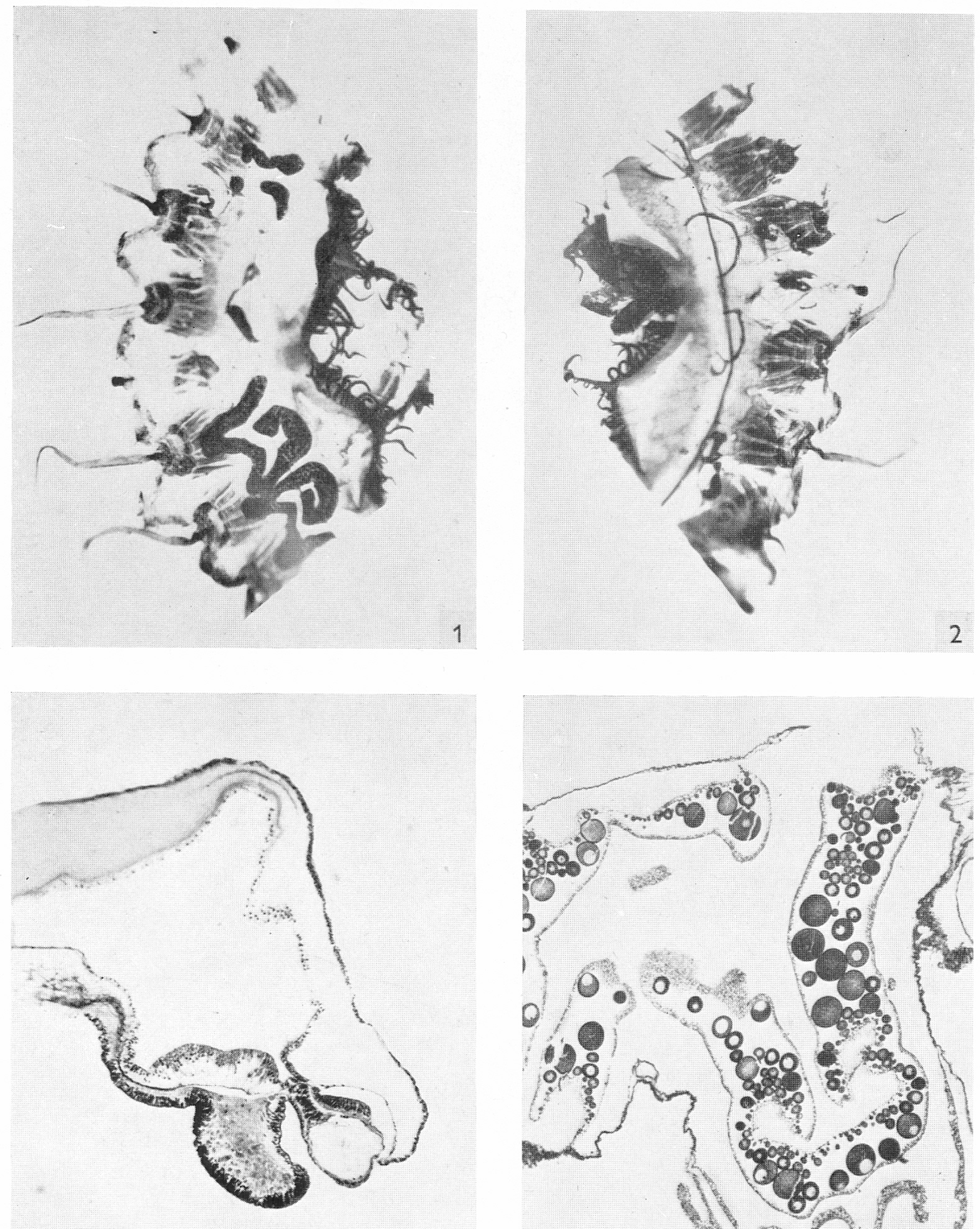

$200 \mu$

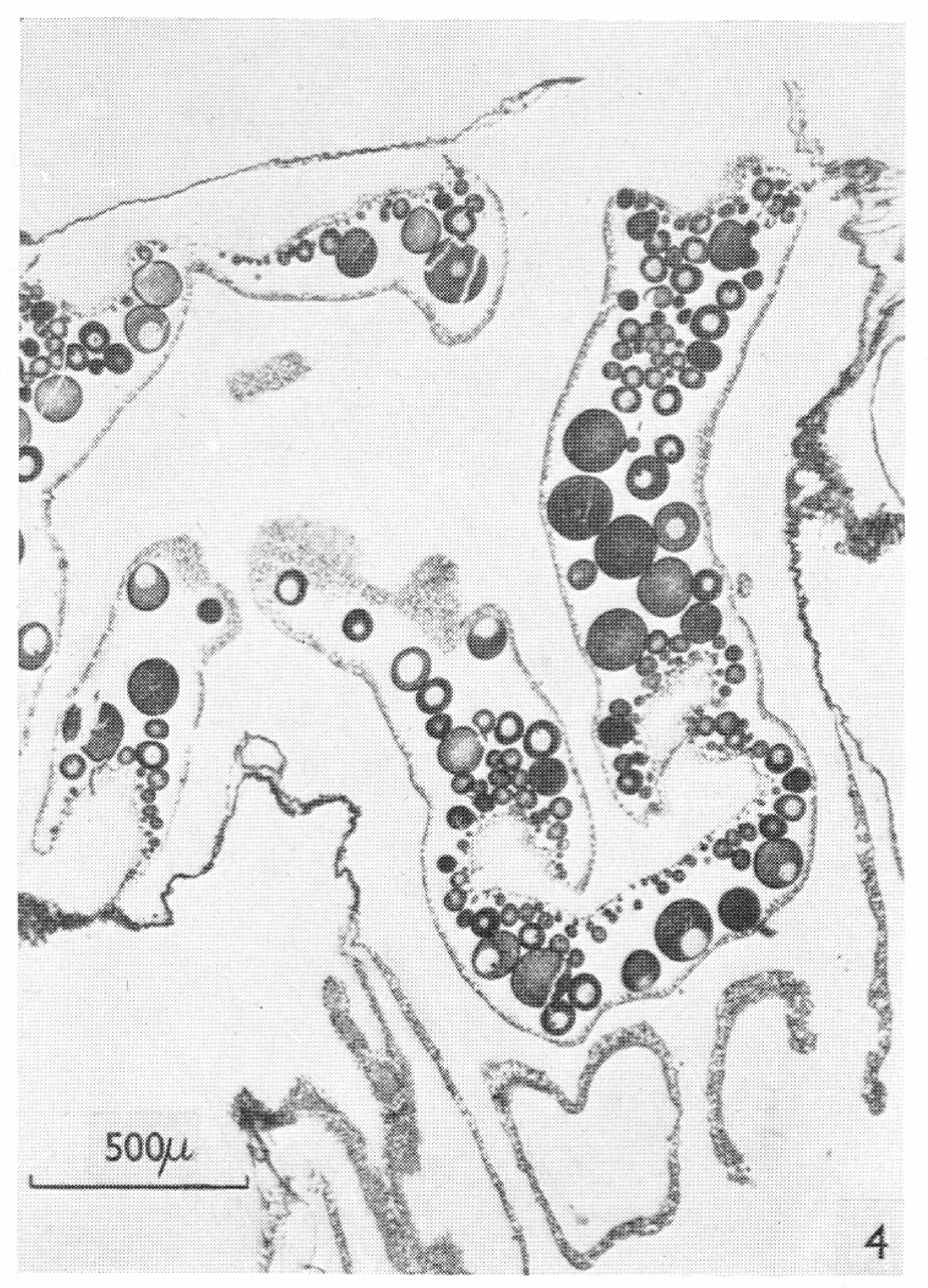




\section{EXPLANATION OF PLATES}

\section{Plate I. Paraphyllina ransoni}

Fig. I. Photograph of specimens about four-fifths natural size; one specimen has been pressed on to the bottom of the glass vessel to show the marginal lappets.

Fig. 2. Sector of umbrella bleached by Mayer's chlorine method, stained with borax carmine, and mounted.

\section{Plate II. Paraphyllina ransoni}

Figs. I, 2. Two halves of the umbrella of the same specimen showing reduction of gonads (male); bleached, stained and mounted as in Pl. I, fig. 2.

Fig. 3. Radial section through rhopalium, stained with haematoxylin and eosin.

Fig. 4. Section through female gonad, stained with haematoxylin and eosin. 